\title{
THE ULTRASTRUCTURE OF GERMINATING BARLEY SEEDS. I. CHANGES IN THE SCUTELLUM AND THE ALEURONE LAYER IN NORDAL BARLEY
}

by

\author{
NIELS H. GRAM \\ Department of Physiology, Carlsberg Laboratory \\ Gamle Carlsberg Vej 10, DK-2500 Copenhagen Valby \\ and \\ Department of Crop Husbandry and Plant Breeding \\ Royal Veterinary and Agricultural University \\ Thorvaldsensvej 40, DK· 1871 Copenhagen V.
}

Keywords: Amyloplast, oleosome, Golgi apparatus, membrane body, lomasome, calcofluor, endosperm degradation

The ultrastructure of the scutellum and the aleurone layer has been examined in seeds of Nordal barley following malting for $0,30,72,120$ and 162 hours at $15^{\circ} \mathrm{C}$. Thick sections from the seeds were stained with Calcofluor White M2R New and examined in the light microscope to determine the extent of cell wall degradation in the endosperm.

The changes in the scutellar parenchyma cells include degradation of the protein bodies and the appearance of vacuoles and prominent amyloplasts. The analysis of a serially sectioned epithelial cell from the scutellum 72 hours after the start of malting revealed a large number of Golgi apparatuses, preferentially located near the cell wall. It is suggested that the presence and location of the Golgi apparatuses are related to enzyme secretion. Following malting for 72 hours or more, the epithelial cells contain lomasomes and membrane aggregates, termed membrane bodies. The analysis indicated that lomasomes originate from the membrane bodies and are involved in the growth of the cell walls of the epithelium. Organelles indicating cellular activity, i.e., rough endoplasmic reticulum, mitochondria and Golgi apparatuses, first appear in the epithelial cells of the scutellum. and later in the cells of the aleurone layer. Furthermore, the degradation of the endosperm starts in the vicinity of the scutellum as judged by the calcofluor staining. Therefore, it is concluded that the scutellar epithelium provides the enzymes during the initial degradation of the endosperm. In seeds malted for 162 hours, aleurone cells with a cytoplasmic organisation indicative of active metabolism are located in the embryo part of the seed, whereas aleurone cells adjacent to unmodified endosperm in the distal end of the same seed show little or no structural sign of activity. 


\section{INTRODUCTION}

The relative roles of the scutellum and the aleurone layer in the degradation of the endosperm during germination and early seedling growth have long been discussed. In 1890 , Brown and Morris (7) concluded, on the basis of light microscopic studies and growth of isolated cereal embryos, that the scutellum secretes enzymes and absorbs the degradation products, and therefore constitutes the only tissue responsible for the enzyme secretion during germination. At the same time, HABERLANDT (14) found that also the aleurone layer was able to secrete enzymes, an observation challenged by Brown and Morris (7), who concluded in a re-examination of HABERLANDT's findings that the aleurone layer was to be regarded solely as a storage tissue, unless sthe presence of a germ capable of development has some mysterious power of influencing the aleurone cells across the intermediate dead tissue of starch containing endosperm, and of so far controlling their metabolic processes as to cause secretion of a specific enzymer.

This power actually exists in the germinating seed and is now known to be gibberellin. The embryo secretes gibberellin $(13,34,44)$, and it has been shown that exogeneously applied gibberellic acid causes considerable ultrastructural changes in aleurone cells $(32,33)$. This discovery led to a large number of investigations concerning the mode of action of gibberellic acid on isolated aleurone layers, and the capability of aleurone cells to produce enzymes necessary for the degradation of the endosperm in the seed is now well established $(5,15,17,19,20,21,23$, $39,40)$. Other studies have, however, shown that also the scutellum secretes enzymes $(2,3,4$, $6,11,12,24,31)$. Analysing cell wall breakdown with calcofluor staining and $\alpha$-amylase transport with fluorescent antibodies, GibBons (12) could establish that wall degradation and enzyme secretion in germinating barley seeds start from the scutellum, and the aleurone cells first become active in secreting $\beta$-glucanases and amylases at later stages of endosperm modification.

The present investigation was carried out to study simultaneously the ultrastructural changes occurring in the scutellum and the aleurone layer in germinating barley seeds, in order to establish times at which the two tissues convert from a dormant into a metabolically active state.

\section{MATERIALS AND METHODS \\ 2.1. Micromalting}

The present analysis was performed on barley seeds, Hordeum vulgare L., variety Nordal, harvest 1979 . The seeds, kindly provided by $\mathrm{Dr}$. J. LARSEN, germinated in a micromalting device developed at the Carlsberg Laboratory. The device consists of a stainless steel box, which contains a rotating cylinder. The cylinder may contain 144 samples of seeds, each sample weighing about 80 grams.

The steeping period lasted 30 hours, comprising 6 hours immersion in water, 18 hours aeration with humidified air followed by an additional 6 hours immersion. The steeping was carried out at $16^{\circ} \mathrm{C}$. Subsequently, the seeds germinated for 132 hours in humidified air with an aeration rate of $71 / \mathrm{min}$. The temperature of the inlet air was $12-13^{\circ} \mathrm{C}$ and near the seeds, the temperature was $14-15^{\circ} \mathrm{C}$. The duration of the entire program thus amounted to 162 hours. Samples were taken after $0,30,72,120$ and 162 hours.

\subsection{Calcofluor staining}

In each sample, 10 seeds were randomly chosen. First, the seeds were cut in three parts by two longitudinal and parallel dorsoventral cuts. The two outer sections were not used in the analysis. The mid section, a $1.2 \mathrm{~mm}$ thick slice, was cleaved by another cut into two slices, 0.6 $\mathrm{mm}$ thick. One of these slices was fixed for the electron microscope investigation (see section 2.3). The other slice was stained with calcofluor in order to analyse the extent of wall degradation in the endosperm $(1,43)$. The staining procedure was as follows: (1) staining with $0.1 \%$ aqueous Calcofluor White M2R New (Cyanamid, USA) for 1-2 minutes; (2) washing in $70 \% \mathrm{v} / \mathrm{v}$ ethanol followed by drying in a stream of air; (3) counterstaining with $0.1 \%$ Fast Green F.C.F. (Gurr/Searle, England) for 1 minute; (4) blotting with a paper tissue to remove excess dye.

The stained sections were analysed in a fluorescence microscope using incident UV-light and photographed. The average modification of 
the endosperm was estimated, and the five seeds, which showed a modification closest to the average, were chosen for the electron microscopic analysis.

\subsection{Fixation}

The embryo part, the dorsal aleurone tissue and ventral aleurone tissue, were cut out of the $0.6 \mathrm{~mm}$ thick seed slices. The different parts of the seed were fixed in $4 \%(\mathrm{v} / \mathrm{v})$ glutaraldehyde in $0.06 \mathrm{M}$-phosphate buffer $(\mathrm{pH}=7.4)$ for 3 hours at room temperature. Following several washes in buffer, the samples were postfixed in $1 \% \mathrm{OsO}_{4}$ in $0.06 \mathrm{M}$-phosphate buffer for $2 \frac{1}{2}$ hours at room temperature, washed twice in buffer, 3 times in distilled water and postfixed/ stained in $2 \%$ aqueous uranyl acetate at $50^{\circ} \mathrm{C}$ for 3 hours. After two washes in distilled water, the samples were dehydrated in a graded alcohol series, embedded in Spurr's low viscosity epoxy resin (36) and polymerized for 12 hours at $70^{\circ} \mathrm{C}$

To prepare the sample representing 0 hours of germination, whole seeds were soaked in $4 \%$ glutaraldehyde for 24 hours at room temperature, since dry seeds cannot be cut. Following immersion, the seeds were treated as described above.

Ultrathin sections (500 A) were cut on a Reichert Om U3 ultramicrotome, equipped with a diamond knife. The sections were double stained in $5 \%$ aqueous uranyl acetate for 15 minutes at $50^{\circ} \mathrm{C}$ and in lead citrate for 15 minutes at $20^{\circ} \mathrm{C}$ in an LKB Ultrostainer 2168 , System Carlsberg.

The sections were analysed in a Siemens 102 electron microscope, at 60 or $80 \mathrm{kV}$.

\section{RESULTS}

\subsection{The parenchyma cells of the scutellum}

The parenchyma cells of the scutellum are spherical, 30-40 $\mu \mathrm{m}$ in diameter and located adjacent to the epithelial cell layer. Figure 1 shows a cross section of the scutellum in a seed before germination, the position of the section being denoted by the arrow in Figure ID.

In dormant seeds, the parenchyma cells are characterized by the presence of a large number of spherical lipid droplets, oleosomes, with a diameter of approximately $0.5 \mu \mathrm{m}$. As can be seen in Figure 1A, oleosomes are mainly located close to the cell wall and around the protein bodies.

Protein bodies appear in the electron microscope as single membrane bounded organelles, spherical in shape and with diameters ranging from 2 to $4 \mu \mathrm{m}$, containing a granular ground substance and one or several inclusions. Protein bodies in the parenchyma cells resemble the aleurone grains in the aleurone layer (ag in Figure 12), but in contrast to the aleurone grains, which contain two different kinds of inclusions, the protein bodies of parenchyma cells possess only one kind. The inclusions appear electron transparent, occasionally containing electron dense material (Figure 1A) and resemble the socalled globoid in aleurone grains (see section 3.4).

Before germination, the parenchyma cells contain a low number of proamyloplasts (Figures $1 \mathrm{~A}$ and $1 \mathrm{~B}$ ), each surrounded by a double membrane. The ground substance of the proamyloplasts is granular and they possess one or a few small starch granules (Figures $1 \mathrm{~A}$ and 1B). Furthermore, internal membranes are often observed in the proamyloplasts (Figure 1B). Mitochondria are present in low numbers and the cristae are poorly developed, indicating a low level of activity. Rough endoplasmic reticulum is seldom observed in parenchyma cells before germination. When it is found, it is preferentially located in the vicinity of the nucleus. Golgi apparatuses were not identified at this stage.

Following malting for 72 hours, a number of distinct changes have occurred in the ultrastructure of the parenchyma cells (compare Figures 1 and 2): The protein bodies have become loose in structure and appear to have been converted into vacuoles (Figure 2A). The oleosomes are no longer concentrated around the protein bodies, and their distribution along the plasmalemma is less pronounced. Both mitochondria and rough endoplasmic reticulum are readily identified in the cells. The mitochondria show distinct cristae, and the rough endoplasmic reticulum is found in all parts of the cytoplasm, although not in large quantity. Typical Golgi apparatuses can be observed at this stage (Figure 2B). The size and number of amyloplasts have increased considerably, the amyloplasts now containing one or 
N. H. GRAM: The ultrastructure of germinating barley seeds. I

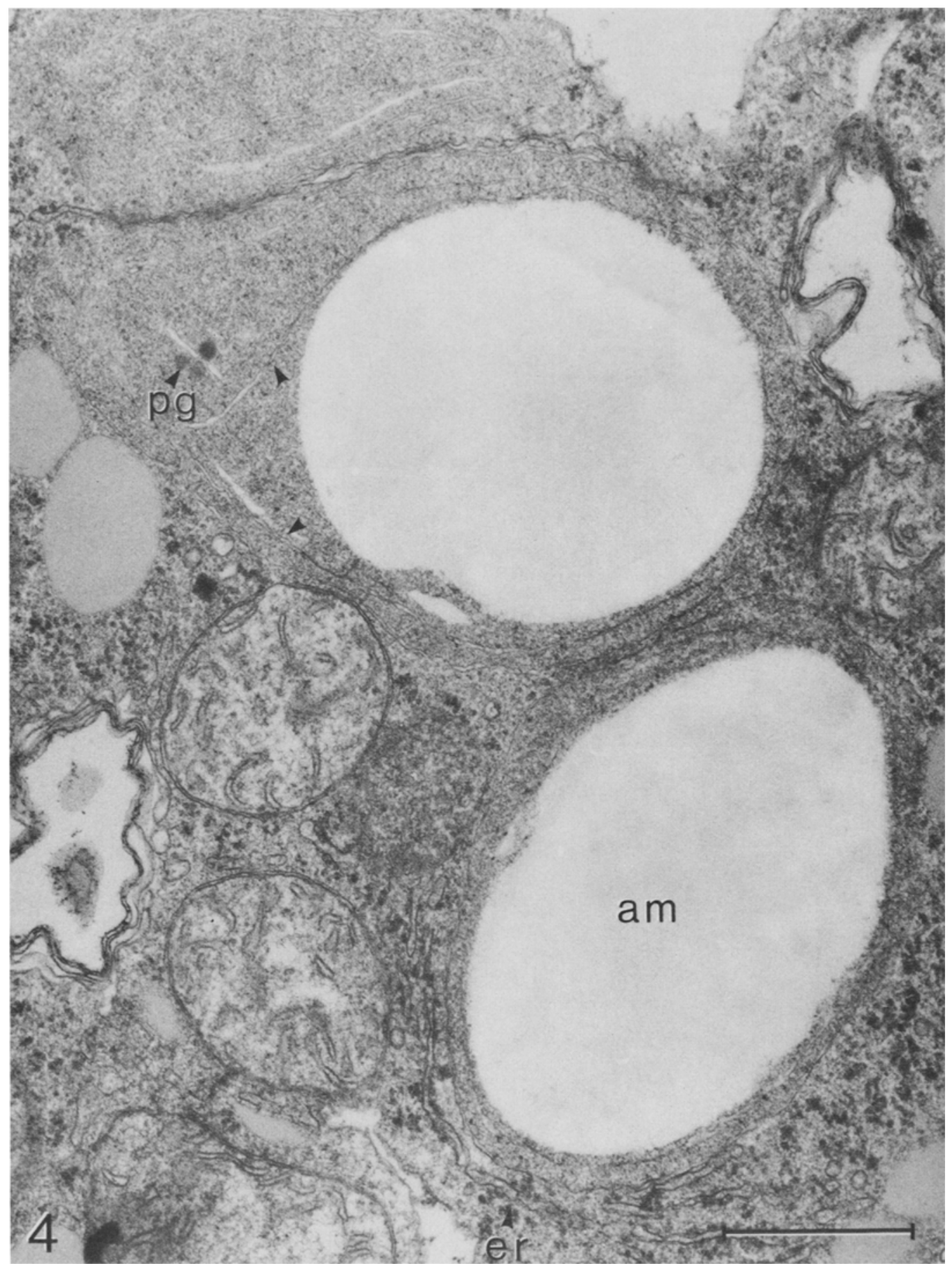

Figure 4. Amyloplasts (am) of an epithelial cell 72 hours after the start of malting.

The amyloplasts are surrounded by a double membrane envelope, and contain prominent electron transparent starch granules, internal membranes (denoted by arrows) and, occasionally, plastoglobuli (pg). The amyloplasts are in close contact with rough endoplasmic reticulum (er). (Bar $=0.5 \mu \mathrm{m})$. 


\section{N. H. Gram: The ultrastructure of germinating barley seeds. I}

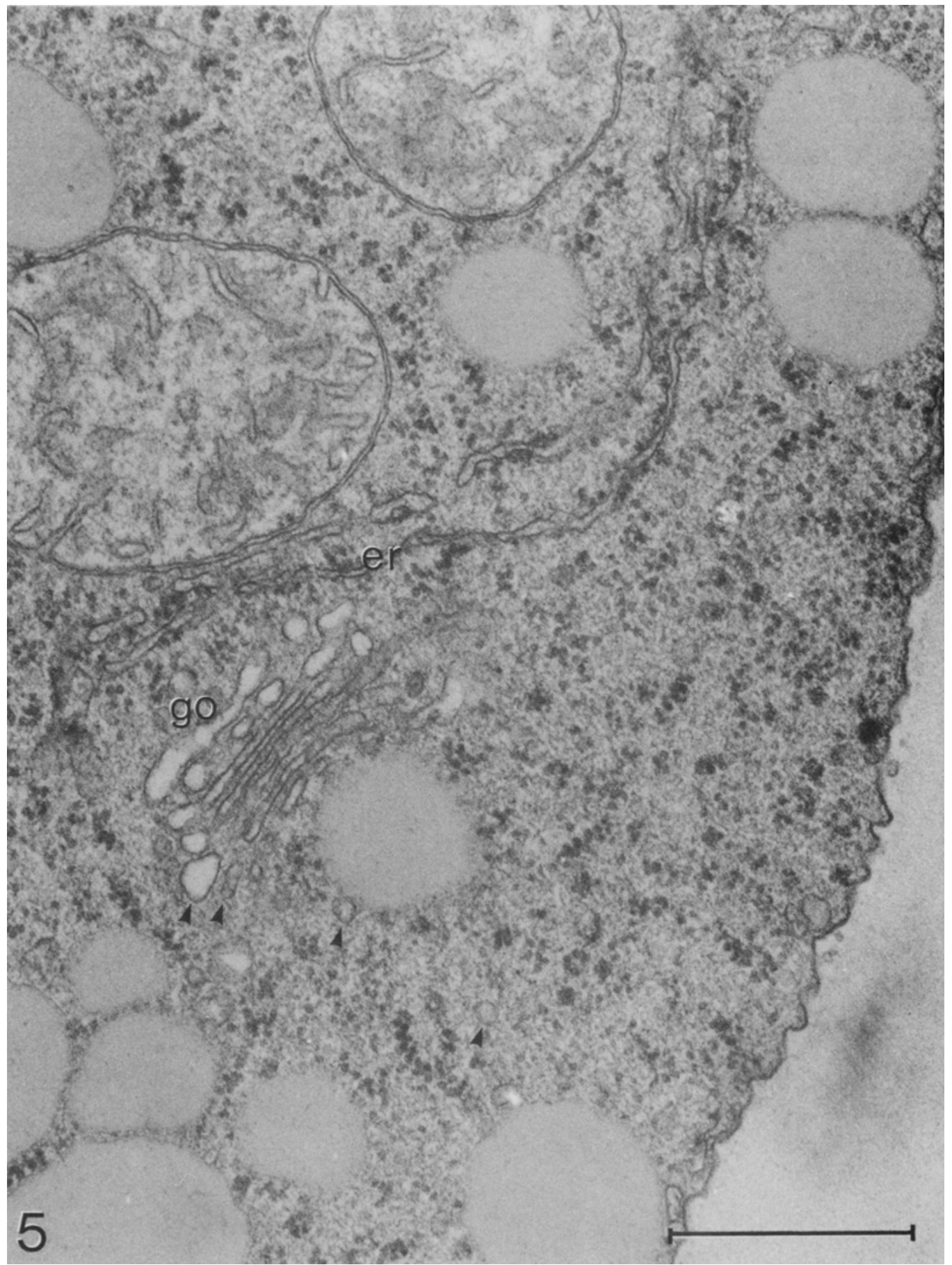

Figure 5. Golgi apparatus (go) from an epithelial cell 162 hours after the start of malting.

The Golgi apparatus consists of 5 or 6 Golgi cisternae and a number of electron transparent vesicles (denoted by arrows). Rough endoplasmic reticulum (er) is located close to the Golgi apparatus. (Bar $=0.5 \mu \mathrm{m}$ ). 
N. H. Gram: The ultrastructure of germinating barley seeds. I

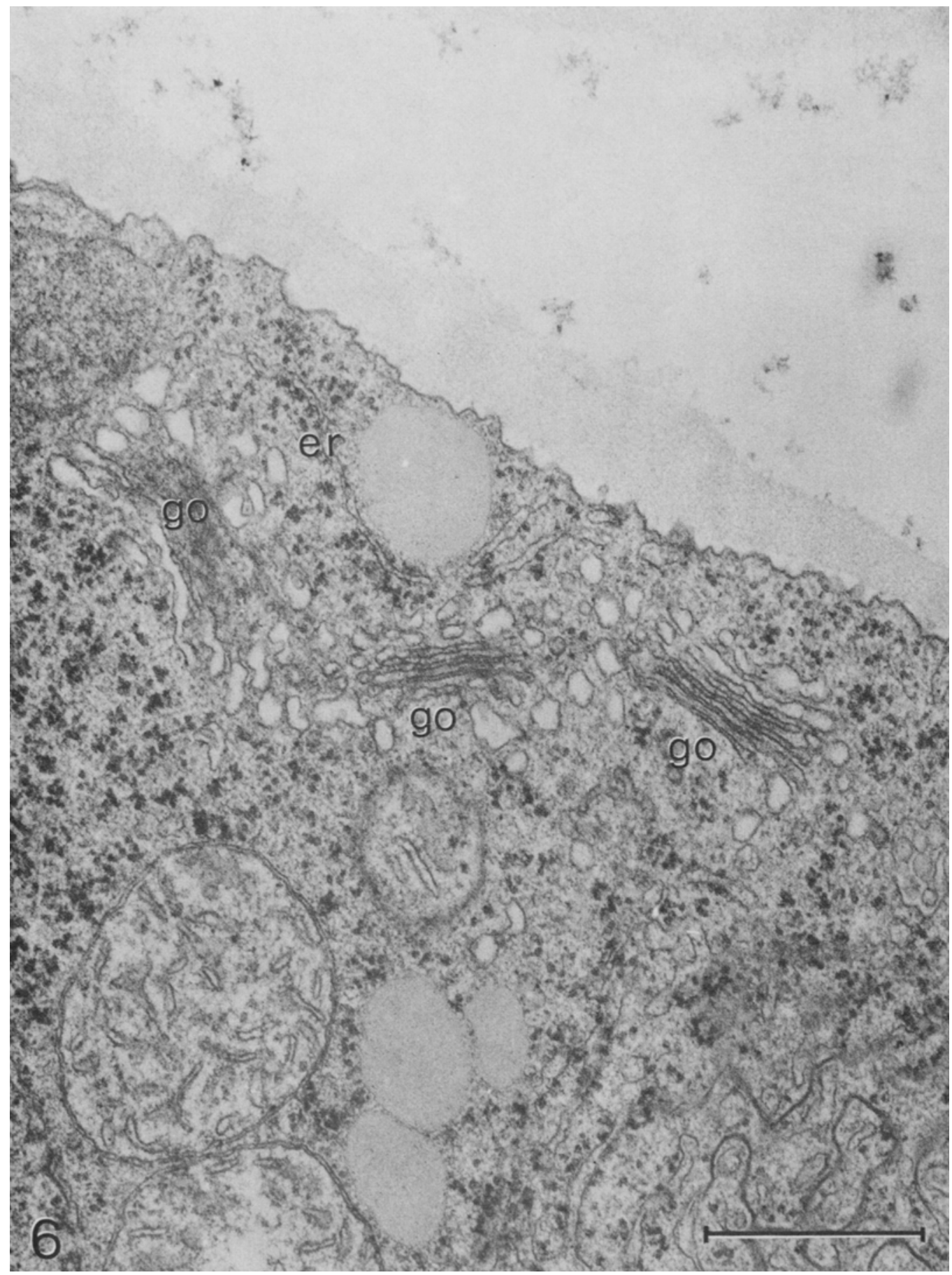

Figure 6. Three Golgi apparatuses (go) located near the cell wall in an epithelial cell 162 hours after the start of malting.

The Golgi apparatus to the right consists of 5 or 6 Golgi cisternae, those closest to the cell wall being more dilated than those facing the center of the cell. Rough endoplasmic reticulum (er) is located in the vicinity of the Golgi apparatuses. $($ Bar $=0.5 \mu \mathrm{m})$. 
more starch granules with diameters up to several micrometers.

After 162 hours of malting (Figure 3) the amyloplasts are the most prominent organelles of the parenchyma cells, the starch granules in the amyloplasts having diameters up to $4 \mu \mathrm{m}$ (Figure 3A). The oleosomes appear to have decreased in number and to be randomly distributed throughout the cytoplasm. In contrast, the number and structure of mitochondria, rough endoplasmic reticulum, Golgi apparatuses and protein bodies remain apparently unchanged, compared to the parenchyma cells 72 hours after the start of malting.

\subsection{The epithelial cells of the scutellum}

The epithelium consists of a single layer of elongate cells, located between the endosperm and parenchyma. Prior to germination, these cells are $30-40 \mu \mathrm{m}$ long and 5-8 $\mu \mathrm{m}$ wide (Figure 1).
The number and distribution, as well as the ultrastructure of the organelles in the epithelial cells, are found to be almost the same as described for the parenchyma cells. However, during the first 72 hours of malting a number of morphological changes mark the switch from a dormant to an active state of the epithelium (compare Figures 1 and 2). Rough endoplasmic reticulum appears in all cells, and the mitochondria, now exhibiting distinct cristae and membranes (Figures $2 \mathrm{~A}$ and $2 \mathrm{C}$ ), have increased in number. These changes are more pronounced in the epithelium than in the parenchyma cells. As in the parenchyma cells, the content of protein bodies is degraded and the protein bodies appear to fuse. Simultaneously, the distribution of the oleosomes change from a preferential location along the plasmalemma and around the protein bodies to a more random one.

The number of amyloplasts has increased in the epithelium, but they appear to be smaller and less frequent than in parenchyma cells. As seen

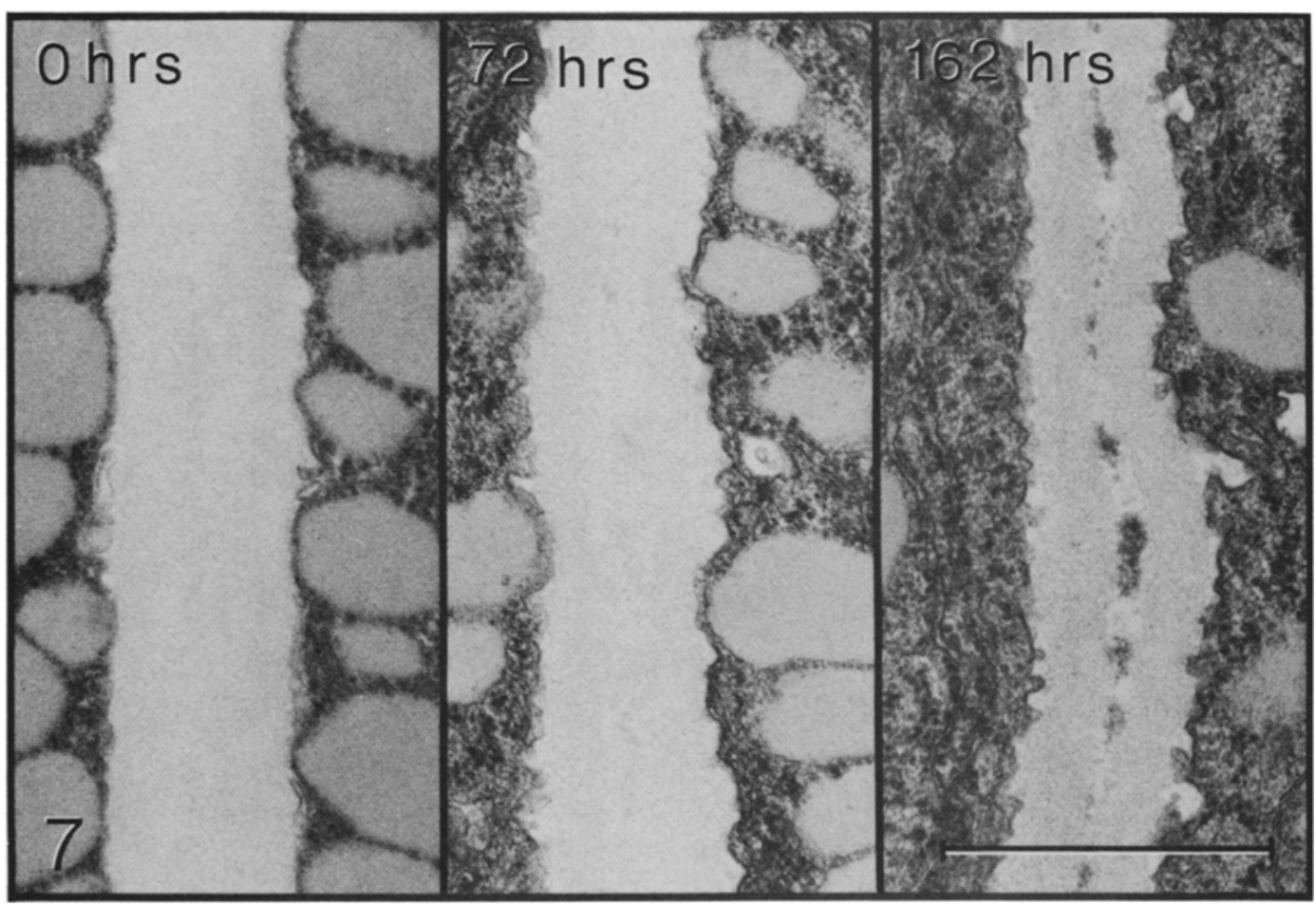

Figure 7. Cell walls of the epithelium 0,72 and 162 hours after the start of malting.

Note the change in shape of the plasmalemma and the concominant formation of an electron transparent zone between the cell walls of neighbouring cells. $(\operatorname{Bar}=1 \mu \mathrm{m})$. 
in Figure 4, the amyloplasts are surrounded by a double membrane and contain a granular ground substance, internal membranes, growing starch granules, and occasionally, plastoglobuli. Often amyloplasts are in close contact with rough endoplasmic reticulum.

Many well defined Golgi apparatuses are observed in the epithelial cells at this stage. In order to map the position of the Golgi apparatuses and to estimate their number, the epithelium was serially sectioned. Fifty-six Golgi apparatuses were identified in a series covering about half a cell, the vast majority (forty-five) being located less than $1 \mu \mathrm{m}$ from the plasmalemma. Only four were in the center of the cell.

Following malting for 162 hours, the development described above has proceeded further (compare Figures 2 and 3). The number of amyloplasts has increased, and the close contact between rough endoplasmic reticulum and the amyloplasts is still observed (Figure 3C). The oleosomes are now distributed throughout the cytoplasm, and appear to have decreased in number. Empty protein bodies have fused to larger vacuoles, and rough endoplasmic reticulum can be found in all cells (Figure 3A).

At this stage, the epithelial cells contain a large number of Golgi apparatuses, each consisting of 4-6 Golgi cisternae, which produce numerous electron transparent vesicles (Figures $3 \mathrm{C}, 5$ and 6). The Golgi cisternae appear to increase in thickness from the forming face to the maturing face (Figure 6). Often Golgi apparatuses are found in groups, which may indicate previous duplications $(9,42)$, and rough endoplasmic reticulum is observed in the immediate vicinity of the Golgi apparatus.

\subsection{Elongation of the epithelial cells}

It has been shown that the scutellar epithelium of barley and other cereals elongate to approximately twice their original length during germination and early seedling growth $(7,26,29,30$, 35). Furthermore, the cells separate and thereby drastically increase the surface area towards the endosperm.

The outline of the plasmalemma becomes irregular as malting proceeds, and neighbouring cells begin to separate along their midlamella, the zone of separation being identifiable by an electron transparent region, often containing electron dense particles (Figure 7).

Small bodies, lomasomes, consisting of membranes devoid of ribosomes are frequently observed near the cell wall in epithelial cells in seeds malted for 72 hours or more (Figure 8). Some of the lomasomes are confluent with the plasmalemma and appear to release their content into the cell wall. Often the lomasomes are in close contact with oleosomes. At the same time, large aggregates of membranes, hereafter termed membrane bodies, are observed in epithelial cells (Figure 9). Membrane bodies are always found inside or in direct contact with the vacuoles originating from protein bodies, and often membrane bodies enclose oleosomes (Figure 9B).

The analysis of serially sectioned epithelial cells 72 hours after the start of malting showed (Figures 10 and 11) that membrane bodies appear to pinch off small bodies, which often fuse with the plasmalemma. The pinched-off bodies are indistinguishable in structure from the lomasomes.

\subsection{The aleurone layer}

The aleurone layer encases the endosperm. It is $2-3$ cells in thickness and is characterized by thick cell walls.

Before germination, aleurone cells show no sign of activity (Figure 12). Oleosomes are present in large numbers and are exclusively located along the cell wall and around the aleurone grains. The aleurone grains, the other major component of aleurone cells, are spherical protein bodies, containing two kinds of inclusions: The so-called globoid inclusion, which normally appears as an electron transparent body, but occasionally containing electron dense material believed to be phytin (16), and the socalled crystalloid inclusion, which appears as a homogeneous body of intermediate electron density, believed to contain protein and carbohydrate (16). Aleurone grains contain one or several globoids, but seldom more than one crystalloid. Plasmodesmata are found between neighbouring cells and are also present between endosperm and aleurone cells (Figure 12B). Organelles resembling mitochondria are observed, but an unequivocal identification was not 


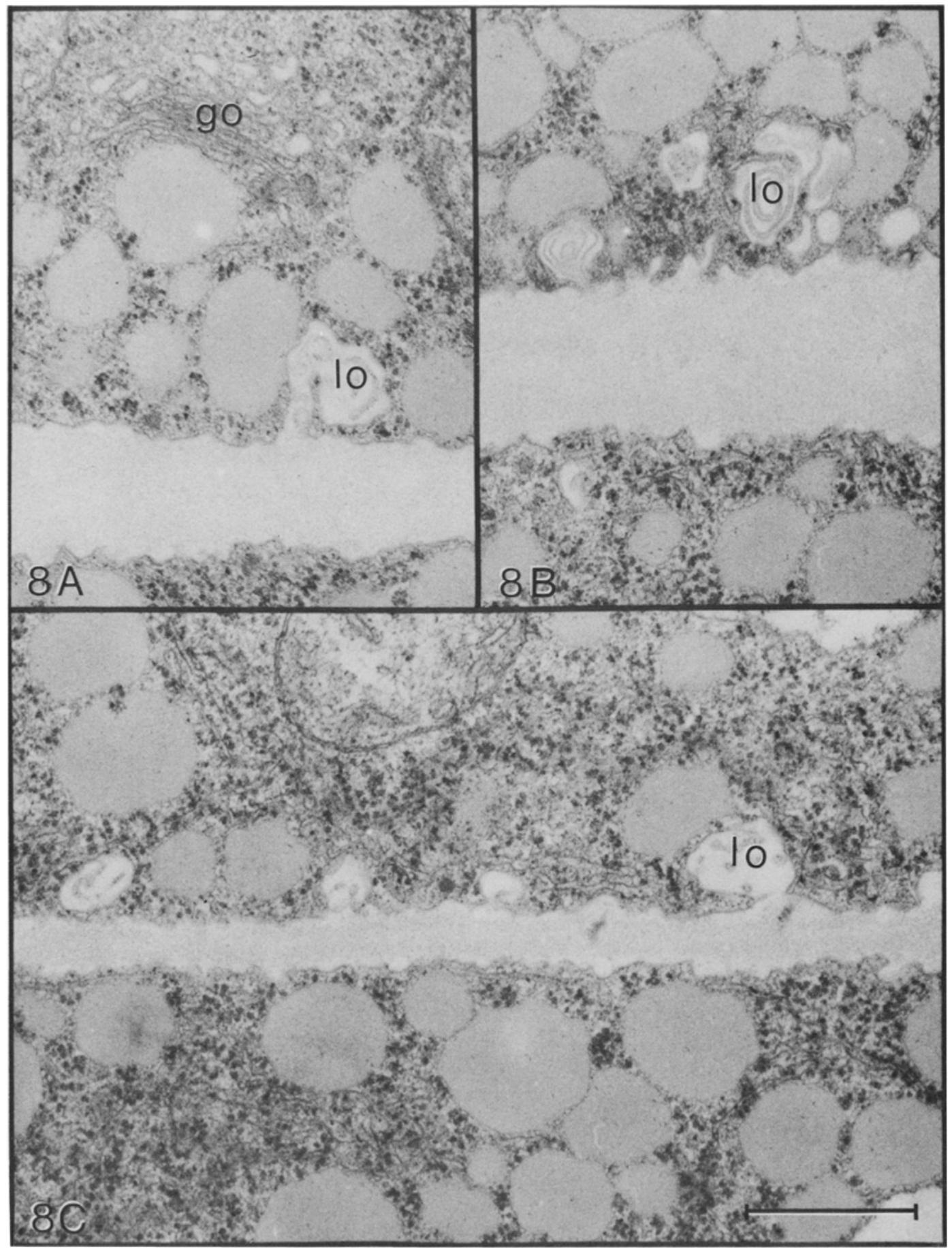

Figure 8. Lomasomes (lo) of epithelial cells 72 hours after the start of malting.

The lomasomes, containing internal membranes, are surrounded by a single membrane. In Figures $8 \mathrm{~A}$ and $8 \mathrm{C}$ the outer membrane of the lomasomes have fused with the plasmalemma. Note that the Golgi vesicles (Figure $8 \mathrm{~A}$ ) are much smaller than the lomasomes and do not contain internal membranes. go, Golgi apparatus. $($ Bar $=0.5 \mu \mathrm{m})$. 


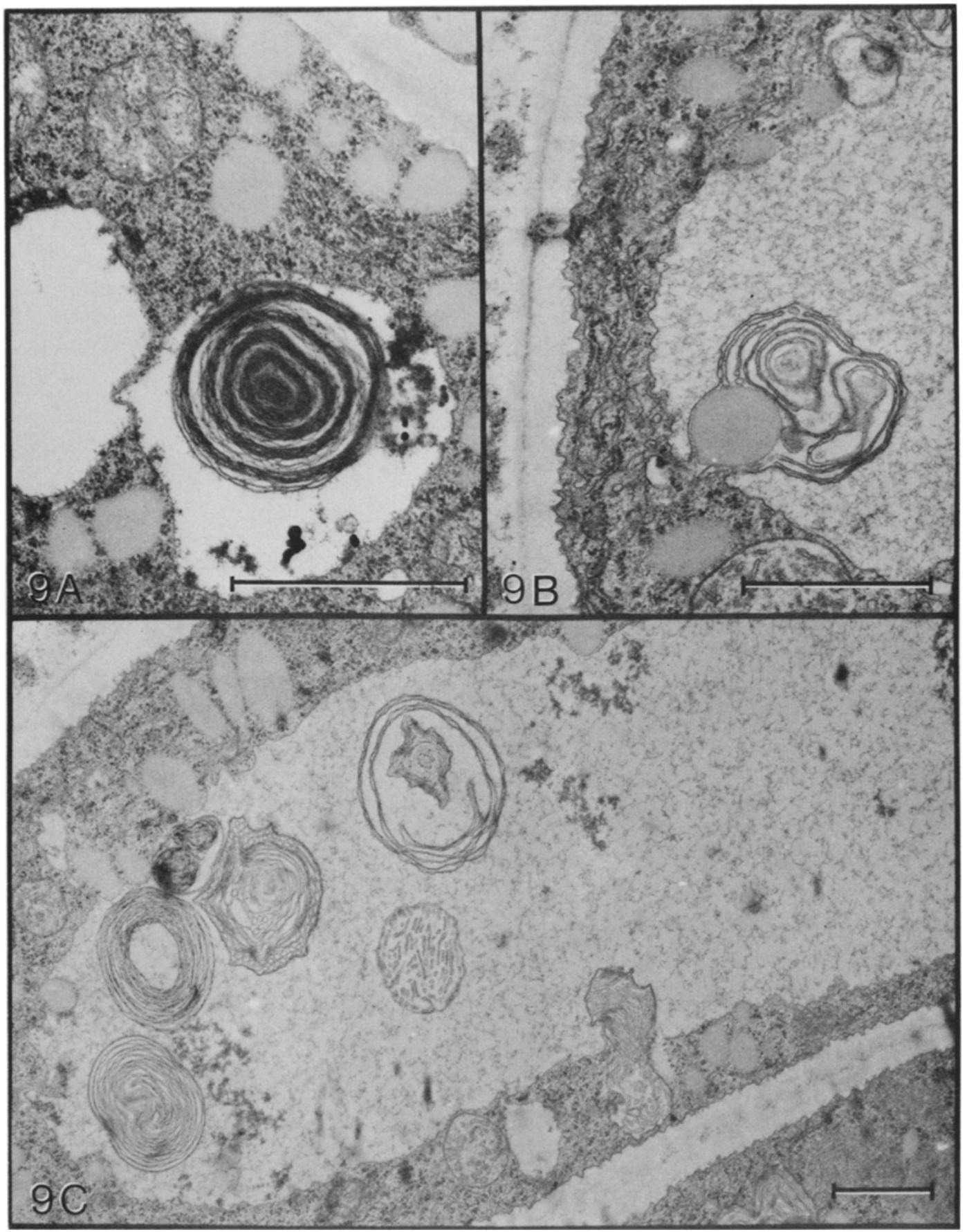

Figure 9. Membrane bodies of epithelial cells 72 hours (Figure 9 A) and 162 hours (Figures 9 B and $9 \mathrm{C}$ ) after the start of malting.

The membrane bodies, consisting of smooth membranes, appear inside or in contact with protein bodies/ vacuoles. Note in Figure $9 \mathrm{~B}$ that a membrane body has enclosed an oleosome. In Figure $9 \mathrm{C}$ a membrane body appears to penetrate the vacuole and approach the cell wall. $($ Bar $=1 \mu \mathrm{m})$. 


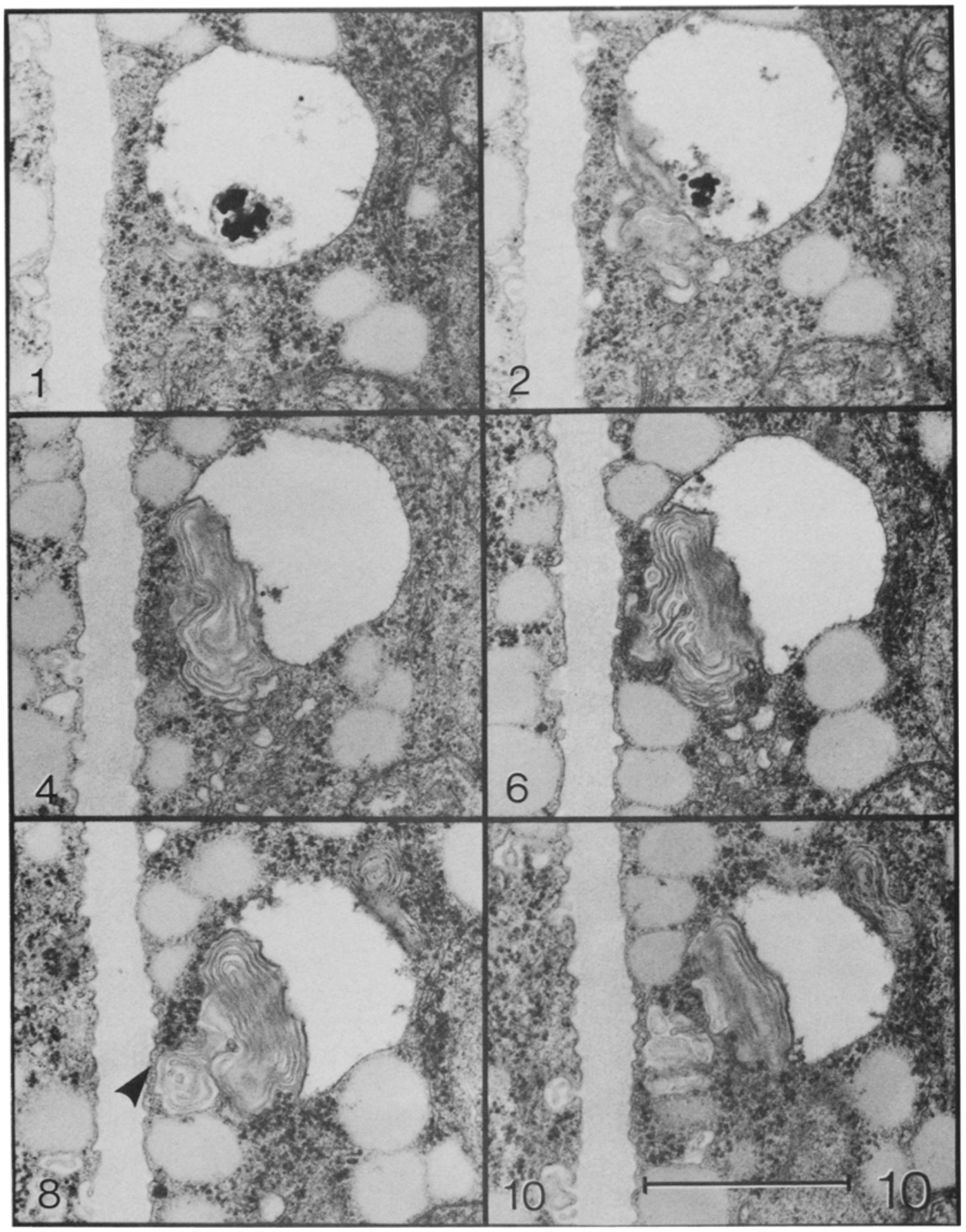

Figure 10. Six sections from a series through a membrane body 72 hours after the start of malting.

The numbers refer to the section numbers. The membrane body attached to the empty protein body (sections 4 and 6) apparently pinches off a lomasome (sections 8 and 10), which is confluent with the plasmalemma in section 8 (arrow). (Bar $=1 \mu \mathrm{m})$. 


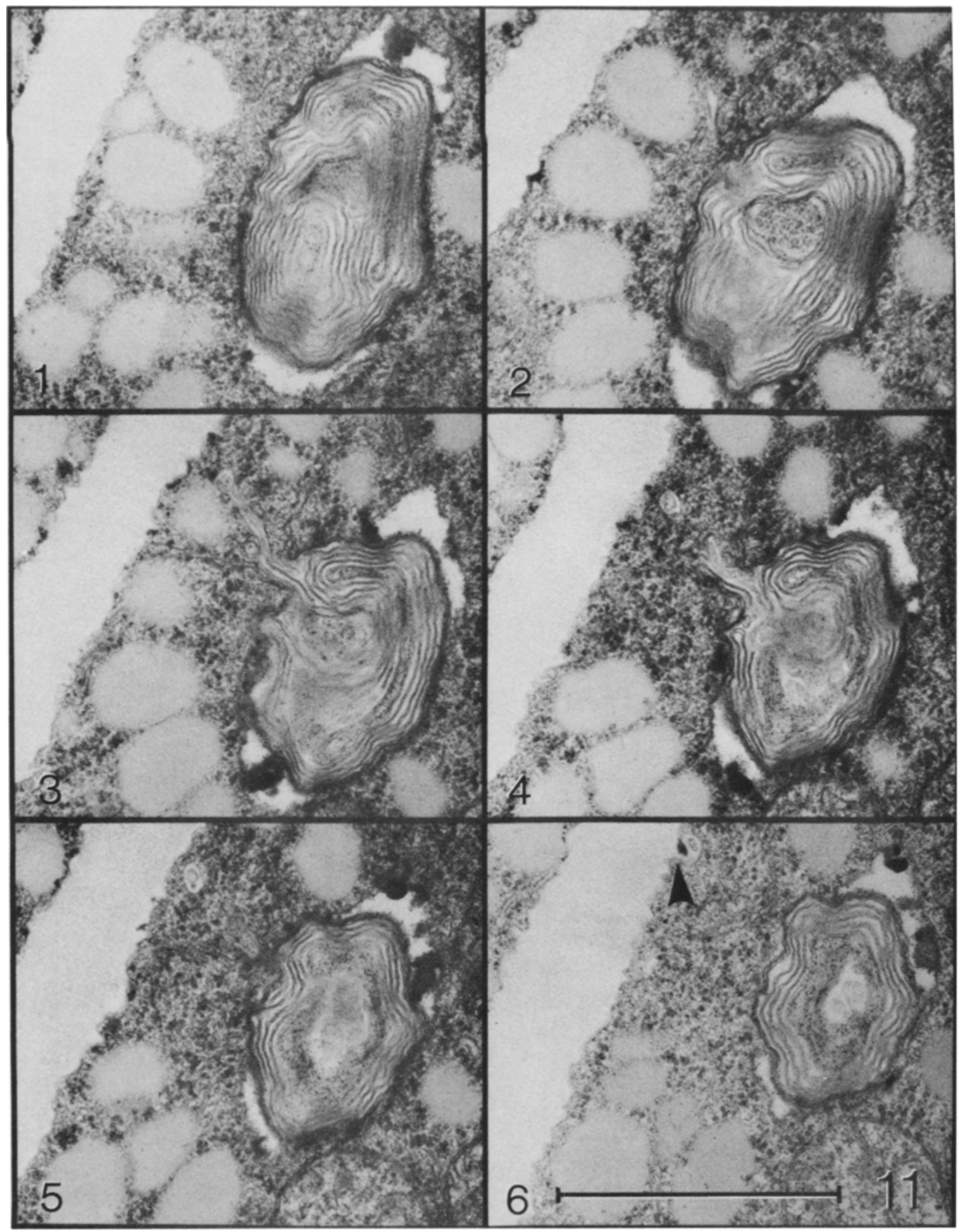

Figure 11. Six consecutive sections through a membrane body 72 hours after the start of malting.

This series reveals a narrow protrusion from the membrane body towards the cell wall (sections 3 and 4). Lomasomes are observed near the cell wall (sections 4 and 5 ), and in section 6 , a lomasome has fused with the plasmalemma. $($ Bar $=1 \mu \mathrm{m})$. 


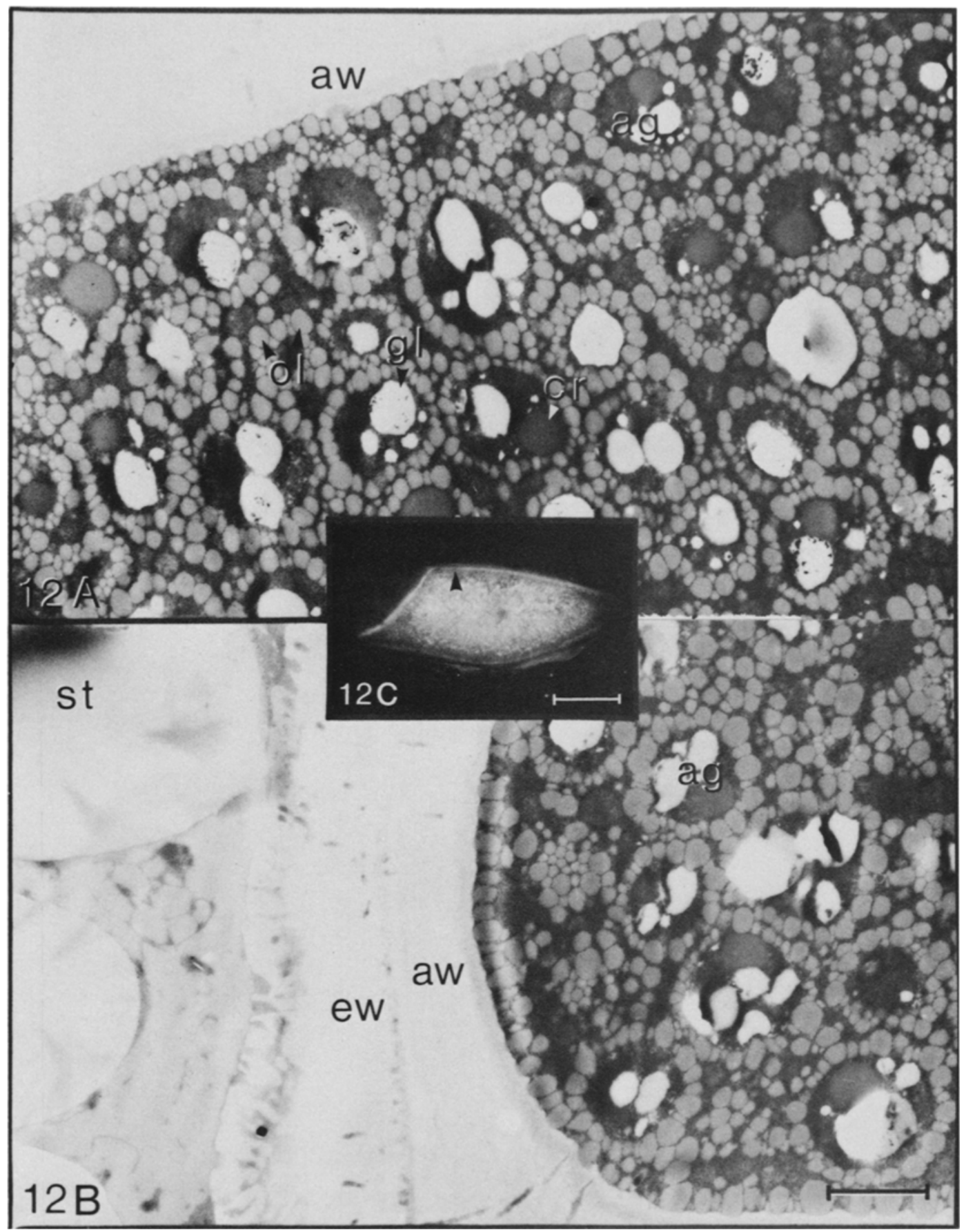

Figure 12. Aleurone cells before germination (the same seed as in Figure 1).

Figure $12 \mathrm{C}$ shows the seed stained with calcofluor. The cell walls of the endosperm fluoresce intensely. The arrow denotes the position, at which the sections have been cut. Note that the oleosomes (ol) are preferentially located around the aleurone grains (ag) and along the plasmalemma. aw, aleurone cell wall; cr, crystalloid; ew, endosperm cell wall; gl, globoid; st, starch granule. Figures $12 \mathrm{~A}$ and $12 \mathrm{~B}:(\mathrm{Bar}=2 \mu \mathrm{m})$, Figure $12 \mathrm{C}$ : (Bar $=2 \mathrm{~mm})$. 


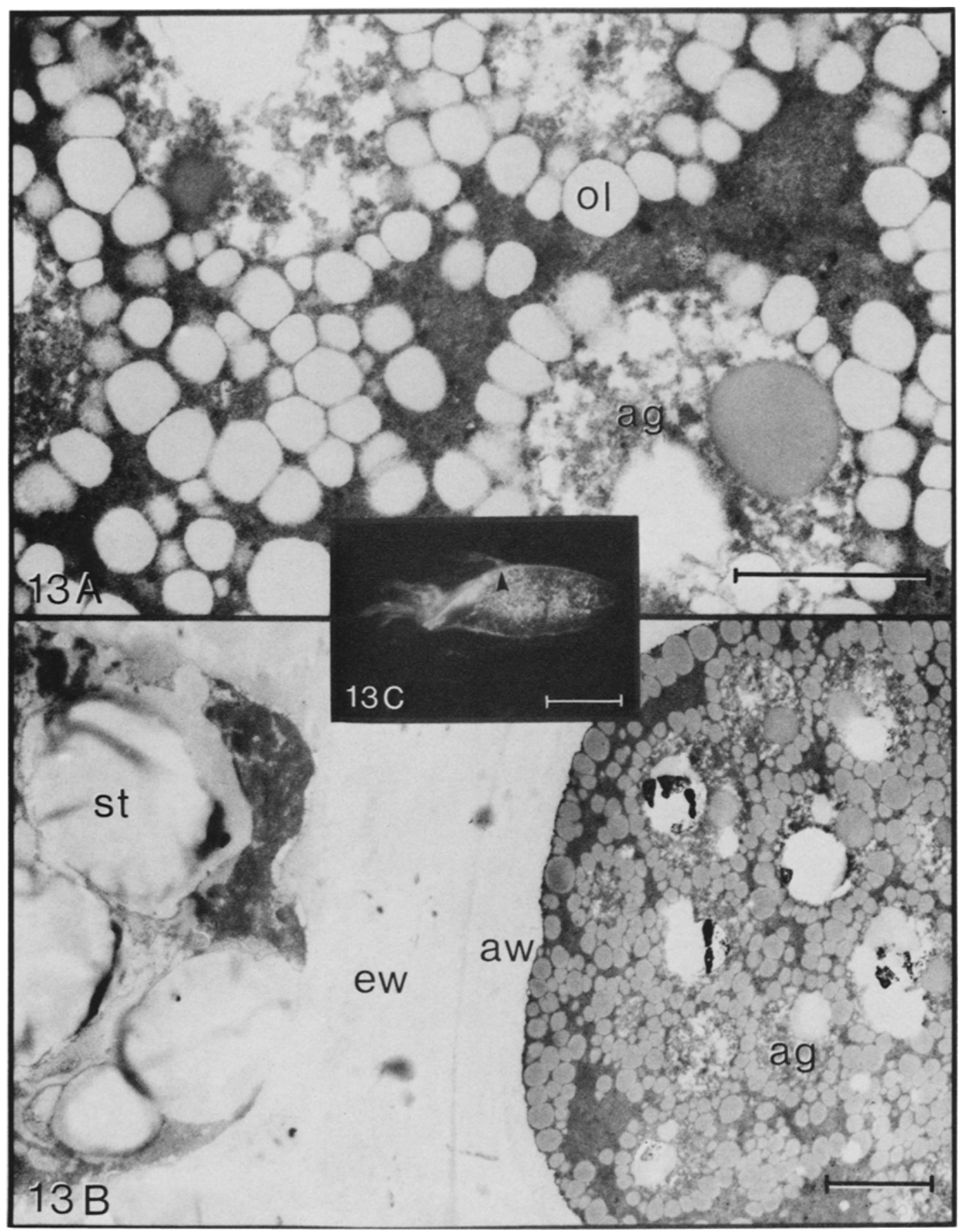

Figure 13. Aleurone cells 72 hours after the start of malting (the same seed as in Figure 2).

Figure $13 \mathrm{C}$ shows the seed stained with calcofluor. The endosperm is degraded in the region adjacent to the scutellum. The arrow denotes the position, at which the sections have been cut. Note in Figure $13 \mathrm{~A}$ the aleurone grains (ag) and the oleosomes (ol), which surround the aleurone grains. The cell walls of the endosperm (ew) and the starch granules (st) in Figure 13 B are still intact. aw, aleurone cell wall. Figure $13 \mathrm{~A}:(\mathrm{Bar}=1 \mu \mathrm{m})$, Figure 13 B: $($ Bar $=2 \mu \mathrm{m})$, Figure $13 \mathrm{C}:($ Bar $=2 \mathrm{~mm})$. 


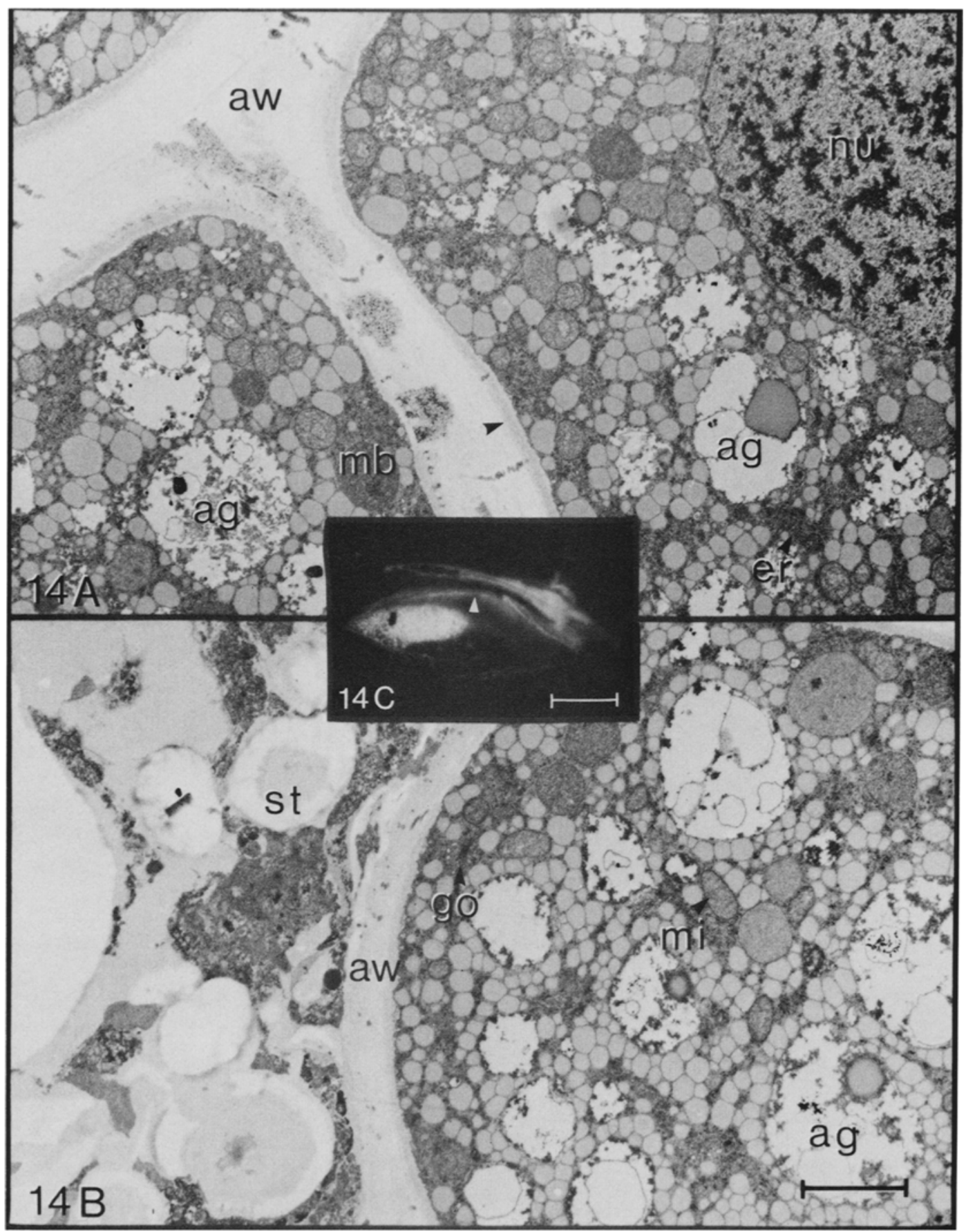

Figure 14. Aleurone cells 162 hours after the start of malting (the same seed as in Figure 3).

Figure $14 \mathrm{C}$ shows the seed stained with calcofluor. Degraded endosperm covers a large area in the embryo end of the seed. The arrow denotes the position, at which the sections have been cut. At this stage distinct mitochondria (mi) and endoplasmic reticulum (er) are observed. Aleurone grains (ag) are almost empty, and microbodies (mb) have appeared in the cells. One Golgi apparatus (go) is present in Figure 14 B. Note in Figure $14 \mathrm{~A}$ the electron dense zone (denoted by an arrow) and the dense inclusions in the cell walls. The endosperm wall adjacent to the aleurone is degraded (compare Figures $13 \mathrm{~B}$ and $14 \mathrm{~B}$ ). aw, aleurone cell wall; nu, nucleus; st. starch granule. Figures $14 \mathrm{~A}$ and $14 \mathrm{~B}:(\mathrm{Bar}=2 \mu \mathrm{m})$. Figure $14 \mathrm{C}:(\mathrm{Bar}=2 \mathrm{~mm})$. 


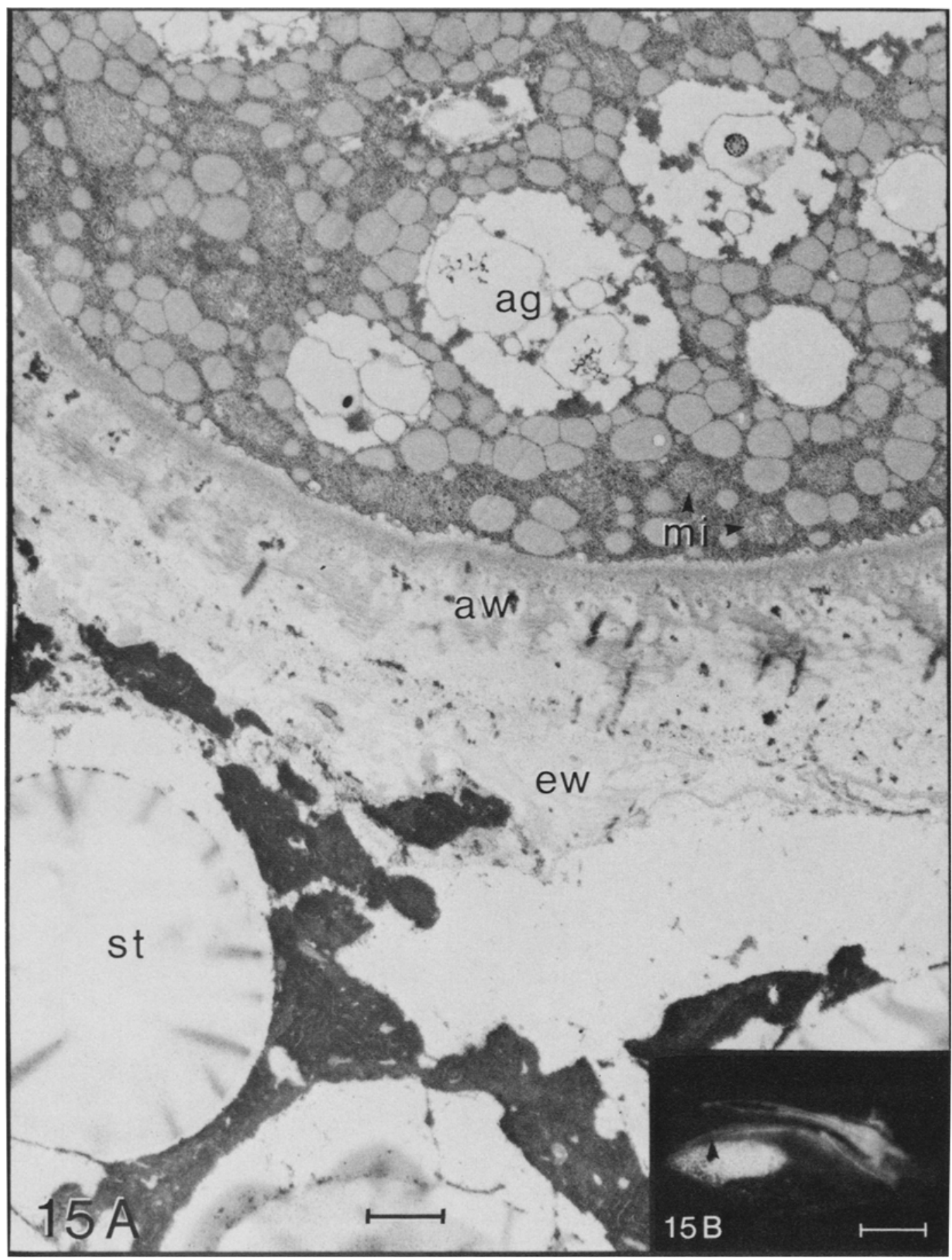

Figure 15. An aleurone cell from the same seed as in Figure 14. The arrow in Figure 15 B denotes the position, at which the section has been cut.

The aleurone cell at this position contains poorly developed mitochondria (mi), almost empty aleurone grains (ag) and a large number of oleosomes. The endosperm wall (ew) adjacent to the aleurone is partially degraded. aw, aleurone cell wall. Figure $15 \mathrm{~A}:(\mathrm{Bar}=1 \mu \mathrm{m})$, Figure $15 \mathrm{~B}:(\mathrm{Bar}=2 \mathrm{~mm})$. 
possible due to the indistinct appearance of the membranes.

After 72 hours of malting, degradation of the endosperm is initiated in the area adjacent to the scutellum (Figure 13C). In agreement with this, only few ultrastructural changes occur in the aleurone layer, the only visible change being a minor degradation of the aleurone grains (Figure 13). The oleosomes remain in the vicinity of the plasmalemma and around the aleurone grains, and distinct mitochondria are not identifiable. Endosperm cell walls and starch granules adjacent to the aleurone layer appear to be unaffected by enzyme degradation. Aleurone cells from other parts of the aleurone layer have the same appearance as the cells shown in Figure 13.

In seeds malted for 162 hours, significant changes are observed (Figure 14). The oleosomes are now distributed apparently at random in the cytoplasm, mitochondria with distinct membranes and cristae are present and the aleurone grains are almost empty, except for the crystalloid, which is still present in many of them. A large number of spherical granular bodies, microbodies, often containing electron dense particles has appeared (Figures 14A and 14B). Rough endoplasmic reticulum is present, although not to the same extent as in epithelial cells. A limited number of Golgi apparatuses is also found (Figure 14B). At this stage, dark inclusions devoid of the fibrillar substructure typical for the cell wall emerge in the walls of the aleurone cells, a change which may indicate partial degradation of the cell wall. Next to the plasmalemma, a more electron dense zone appears in the cell wall (denoted by arrow in Figure 14A). This zone is never invaded by the dark inclusions.

After 162 hours of malting, the aleurone layer in the distal end of the seed still appears inactive as judged by the number and structure of the cell organelles (Figure 15). Mitochondria are ill defined, and neither rough endoplasmic reticulum nor Golgi apparatuses are observed. The micrograph in Figure 15 shows that within this region the cell walls of the endosperm are only partially degraded, and intact starch granules are present.

\section{DISCUSSION}

The primary aim of this study is to characterize the temporal changes in the ultrastructure of the scutellum and the aleurone layer in germinating barley seeds and to relate the changes in the two tissues to the degradation of the endosperm.

The calcofluor staining technique shows that the degradation of the cell walls of the endosperm starts in the vicinity of the scutellum, and progresses towards the distal end of the seed as malting proceeds (compare Figures 1D, 2D and 3D).

In the samples taken 72 hours after the start of malting, degraded endosperm covers a small area adjacent to the scutellum (Figure 2D). The epithelial cells in these samples contain large amounts of rough endoplasmic reticulum, distinct mitochondria and Golgi apparatuses, whereas the aleurone layer appears similar to that of dormant seeds. Therefore, only the ultrastructure of the epithelial cells of the scutellum reflects a cytoplasmic organisation of cells able to produce major amounts of the enzymes required for the degradation of the endosperm during this initial period of malting. These results are in agreement with the findings of GibBons $(11,12)$ and Окамото et al. (31), who demonstrated that $\alpha$-amylases, $\beta$-glucanases, proteinases, as well as ribonuclease first appear in the scutellar region of the endosperm in germinating seeds.

The present study has shown that morphological changes indicative of cellular activity do not appear in the aleurone layer until after 72 hours of malting at $15^{\circ} \mathrm{C}$. The ultrastructural changes occuring in the cells after 72 hours are very similar to those described for the epithelial cells, i.e. degradation of protein bodies (aleurone grains), redistribution of oleosomes, and development of rough endoplasmic reticulum, mitochondria and Golgi apparatuses. Furthermore, a large number of microbodies appears in the aleurone cells. The ultrastructural changes in the aleurone layer in the present study are in agreement with the observations in earlier studies of barley aleurone $(8,10,18,22,25)$.

Seeds malted for 162 hours exhibit extensive degradation of the cell walls in the endosperm (Figure 3D), the modified area being located in the embryo part of the seed and the unmodified cells in the distal end. The present study revealed 
a possible correlation between the ultrastructure of the aleurone cells and the degradation of the neighbouring endosperm, since apparently active aleurone cells were always found adjacent to modified endosperm near the embryo and never adjacent to unmodified endosperm closer to the distal end of the seed. Aleurone cells showing no sign of activity were found adjacent to unmodified endosperm and also adjacent to the zone between modified and unmodified endosperm. These findings are in agreement with the hypothesis that the activation of the aleurone cells is mediated by diffusible gibberellin originating in the embryo end and moving towards the distal end of the seed. Addition of this hormone to germinating seeds results in an acceleration of ultrastructural changes in the aleurone cells, signifying an increased activity in the cytoplasm $(19,20)$, and an enhanced modification of the endosperm close to the aleurone layer (12).

The epithelial cells of the scutellum have been investigated in barley $(28,29)$, wheat $(37,38)$ and other grasses (35). The overall morphological changes occuring in germinating seeds are the same in all species, i.e. degradation and vacuolation of protein bodies, development of mitochondria, rough endoplasmic reticulum and Golgi apparatuses, which is in agreement with the present findings. NiEuWdORP and BuYs (29), investigating germinating barley seeds, reported that Golgi apparatuses did not increase in numbers. In contrast to this, the present analysis of serially sectioned epithelial cells revealed an impressive development of these organelles. In the half cell, which was examined by serial sectioning, 56 Golgi apparatuses were identified. the vast majority being located near the cell wall. The development of more than one hundred Golgi apparatuses in the entire cell during the first 72 hours of malting and their preferential location along the cell wall probably relates to the secretion of the enzymes required for degradation of the endosperm. The walls at the tip of the epithelial cells are devoid of ectodesmata, which could serve as transport channels for the enzymes into the endosperm (Figure 3A). One has thus to conclude that the enzymes are secreted through the microfibrillar network of the cell walls. As the epithelial cells elongate, they separate along their lateral walls, and enzymes can therefore also be secreted through the lateral walls. In this connection it is of interest that plasmodesmata between neighbouring epithelial cells are restricted to the basal portion of the cells (Figures 2A and 3A).

Besides enzyme secretion, the Golgi apparatus is considered to be responsible for cell wall formation and growth (for review 27, 41). Morphological evidence supporting this role of the Golgi vesicles in wall growth is not found in the present study of the scutellar epithelium. On the other hand, a morphological continuity between protein bodies, membrane bodies, lomasomes and the cell wall is indicated in Figures 811: Membrane bodies develop inside or in contact with emptying protein bodies or vacuoles, and subsequently these membrane bodies pinch off lomasomes, which migrate to and fuse with the plasmalemma, thereby contributing to the growth of the cell wall. Membrane bodies and lomasomes are always found together in epithelial cells from seeds malted 72 hours or longer, whereas they are seldom present in parenchyma and aleurone cells, which do not enlarge during malting. These observations support the hypothesis that membrane bodies and lomasomes are involved in the growth of the cell walls of the scutellar epithelium.

\section{ACKNOWLEDGEMENTS}

I wish to express my sincere gratitude to Professor Diter von Wettstein, who besides suggesting the investigation also greatly influenced this work through inspiring guidance and discussions together with Dr. Søren Rasmussen and Dr. Preben Holm. Their assistance in preparing this communication is also highly appreciated. I especially thank BIBI STAMPE ANDERSEN for outstanding technical assistance, and Dr. Jørgen LARSEN for providing the seeds. Finally, the assistance of BENT HANSEN, ANNSofi Steinholtz and Jean SAGE is gratefully acknowledged.

\section{REFERENCES}

1. Aastrup, S. \& K. Erdal: Quantitative determination of endosperm modification and its relationship to the content of $1,3: 1,4-\beta$-glucans during malting of barley. Carlsberg Res. Commun. $45,369-379(1980)$ 
2. Briggs, D. E.: Development of enzymes by barley embryos in vitro. J. Inst. Brew. 68, 470475 (1962)

3. Briggs, D. E.: Origin and distribution of $\alpha$ amylase in malt. J. Inst. Brew. 70, 14-24 (1964)

4. BRIGGS, D. E.: $\alpha$-amylase in germinating decorticated barley - I. $\alpha$-amylase, conditions of growth and grain constituents. Phytochemistry 7, 513529 (1968)

5. Briggs, D. E.: Enzyme formation, cellular breakdown and the distribution of gibberellins in the endosperm of barley. Planta 108, 351-358 (1972)

6. Briggs, D. E. \& V. J. Clutterbuck: Generation of $\alpha$-amylase in germinating Hordeum distichon. Phytochemistry 12, 1047-1050 (1973)

7. Brown, H. T. \& G. H. Morris: Researches on the germination of some of the graminex. J. Chem. Soc. 57, 458-528 (1890)

8. Buttrose, M. S.: Ultrastructure of barley aleurone cells as shown by freeze-etching. Planta 96, 13-26 (1971)

9. Domozych, D. S., K. D. Stewart \& K. R. Matrox: Development of the cell wall in Tetraselmis: Role of the Golgi apparatus and extracellular wall assembly. J. Cell Sci. 52, 351371 (1981)

10. Eb, VAN DeR A. A. \& P. J. Nieuwdorp: Electron microscopic structure of the aleurone cells of barley during germination. Acta Bot. Neerl. 15 , 690-699 (1967)

11. Gibbons, G. C.: On the localisation and transportation of $\alpha$-amylase during germination and early seedling growth of Hordeum vulgare. Carlsberg Res. Commun. 44, 353-366 (1979)

12. Gibions, G. C.: On the sequential determination of $\alpha$-amylase transport and cell wall breakdown in germinating seeds of Hordeum vulgare. Carlsberg Res. Commun. 45, 177-184 (1980)

13. Groat, J. I. \& D. E. Briggs: Gibberellins and aamylase formation in germinating barley. Phytochemistry 8, 1615-1627 (1969)

14. Haberlandi, G.: Die Kleberschicht des Grasendospermes als Diastase ausscheidendes Drüsen Gewebe. Ber. Deutsch. Bot. Gesell. 8, 40-48 (1890)

15. Jacobsen, J. V. \& R. B. Knox: Cytochemical localization and antigenicity of $\alpha$-amylase in barley aleurone tissue. Planta 112, 213-224 (1973)

16. Jacobsen, J. V., R. B. Knox \& N. A. Pyliotis: The structure and composition of aleurone grains in the barley aleurone layer. Planta 101, 189209 (1971)

17. JACOBSEN, J. V. \& J. E. Varner: Gibberellic acid-induced synthesis of protease by isolated aleurone layers of barley. Plant Physiol. 42, 1596-1600 (1967)

18. JONES, R. L.: The fine structure of barley aleurone cells. Planta 85, 359-375 (1969)

19. Jones, R. L.: Gibberellic acid and the fine structure of barley aleurone cells. I. Changes during the lag-phase of $\alpha$-amylase synthesis. Planta 87, 119-133 (1969)

20. JONES, R. L.: Gibberellic acid and the fine structure of barley aleurone cells. II. Changes during the synthesis and secretion of $\alpha$-amylase. Planta 88, 73-86 (1969)

21. JONES, R. L.: Fractionation of the enzymes of the barley aleurone layer: Evidence for a soluble mode of enzyme release. Planta 103, 95-109 (1972)

22. JONES, $R$. L.: Quantitative and qualitative changes in the endoplasmic reticulum of barley aleurone layers. Planta 150, 70-81 (1980)

23. JoNes, R. L. \& C. RU-FANG: Immunohistochemical localization of $a$-amylase in barley aleurone cells. J. Cell Sci. 20, 183-198 (1976)

24. Kirsop, B. H. \& J. R. A. Pollock: Studies in barley and malt. XII. Interaction between the embryo and the endosperm of barley during malting. J. Inst. Brew. 64, 227-233 (1958)

25. LOCY, R. \& H. KENDE: The mode of secretion of $a$-amylase in barley aleurone layers. Planta 143 , 89-99 (1978)

26. Macleod, A. M. \& G. H. Palmer: The embryo of barley in relation to modification of the endosperm. J. Inst. Brew. 72, 580-589 (1966)

27. Mollenhauer, H. H. \& D. J. Morré: Golgi apparatus and plant cell secretion. Ann. Rev. Pl. Physiol. 17, 27-46 (1966)

28. NiEUWDORP, P. J.: Electron microscopic structure of the epithelial cells of the scutellum of barley. The structure of the epithelial cells before germination. Acta Bot. Neerl. 12, 295-301 (1963)

29. NieuWDORP, P. J. \& M. C. Buys: Electron microscopic structure of the epithelial cells of the scutellum of barley. II. Cytology of the cells during germination. Acta Bot. Neerl. 13, 559565 (1964)

30. O'Brien, J. A.: Cytoplasmic inclusions in the glandular epithelium of the scutellum of Triticum aestivum and Secale cereale. Am. J. Bot. 29, 479-491 (1942)

31. Okamoto, K., H. Kitano \& T. akazawa: Biosynthesis and excretion of hydrolases in germinating cereal seeds. Plant and Cell Physiol. 21, 201-204 (1980)

32. Paleg, L. G.: Physiological effects of gibberellic acid. II. On starch hydrolyzing enzymes of 
N. H. Gram: The ultrastructure of germinating barley seeds. I

barley endosperm. Plant Physiol. 35, 902-906 (1960)

33. Paleg, L. G. \& B. Hyde: Physiological effects of gibberellic acid. VII. Electron microscopy of barley aleurone cells. Plant Physiol. 39. 673680 (1964)

34. RadLeY, M.: Site of production of gibberellinlike substances in germinating barley embryos. Planta 75, 164-171 (1967)

35. Smart, M. G. \& T. P. O'Brien: Observations on the scutellum. I. Overall development during germination in four grasses. Austr. J. Bot. 27 391-401 (1979)

36. SpurR, A. R.: A low-viscosity epoxy resin embedding medium for electron microscopy. J. Ultrastruct. Res. 26, 31-43 (1969)

37. Swift, J. G. \& T. P. O'Brien: The fine structure of the wheat scutellum before germination. Austr. J. Biol. Sci. 25, 9-22 (1972)

38. SwiFT, J. G. \& T. P. O'Brien: The fine structure of the wheat scutellum during germination. Austr. J. Biol. Sci. 25, 469-486 (1972)
39. VARNER, J. E: Gibberellic acid controlled synthesis of $\alpha$-amylase in barley endosperm. Plant Physiol. 39, 413-415 (1964)

40. VIGIL, E. L. \& M. RudDAT: Effect of gibberellic acid and actinomycin D on the formation and distribution of rough endoplasmic reticulum in barley aleurone cells. Plant Physiol. 51, 549558 (1973)

41. Whaley, W. G.: The Golgi apparatus. Cell Biol. Monogr. Vol 2, Springer Verlag, Vienna and New York. (1975)

42. Whaley, W. G. \& M. Dauwalder: The Golgi apparatus, the plasma membrane and functional integration. Int. Rev. Cytol. 58, 199-245 (1979)

43. WOOD, P. J. \& R. G. FULCHER: Interaction of some dyes with cereal $\beta$-glucans. Cereal Chem. $55,952-966(1978)$

44. Yомо, Н. \& H. Iinuma: Production of gibberellin-like substance in the embryo of barley during germination. Planta 71, 113-118 (1966) 
Figure 1. Cross section through the scutellum in a barley seed before germination.

1A. Survey micrograph showing parenchyma (upper part) and epithelium (lower part). The parenchyma and the epithelium contain a large number of protein bodies (pr) and oleosomes (ol), but only few mitochondria (mi) and proamyloplasts. The endoplasmic reticulum (er) is scarce in both cell types. The protein bodies differ in electron density in the parenchyma cells, while those of the epithelium are of the same, electron transparent type. Note in both cell types that the oleosomes are preferentially located in the vicinity of the plasmalemma. In the parenchyma also protein bodies, especially those of high electron density, are surrounded by oleosomes. nu. nucleus; pl, plasmodesma. $(\mathrm{Bar}=2 \mu \mathrm{m})$.

1B. Higher magnification of the upper framed area in Figure 1A. The micrograph shows two proamyloplasts (pam), each containing starch granules and internal membranes. Note the two plasmodesmata between the epithelial and parenchyma cells to the left in the micrograph. (Bar $=0.5 \mu \mathrm{m}$ ).

1C. Higher magnification of the lower framed area in Figure 1A. The micrograph includes two protein bodies and one proamyloplast, mitochondria are present in the lower part. (Bar $=0.5 \mu \mathrm{m}$ ).

1D. Longitudinal section of the seed used for the ultrathin sectioning, stained with calcofluor and photographed in UV-light. The dye bound to the cell walls of the endosperm (en) fluoresce intensely. The arrow denotes the position, at which the section in Figure $1 \mathrm{~A}$ has been cut. em, embryo. (Bar $=1 \mathrm{~mm}$ ).

Figure 2. Cross section through the scutellum in a barley seed 72 hours after the start of malting.

$2 \mathrm{~A}$. Survey micrograph showing parenchyma (upper part) and epithelium (lower part). The parenchyma now contains vacuole-like structures (va) and only few electron transparent protein bodies. Also the protein bodies of the epithelium have a low electron density. In both cell types, the oleosomes are no longer located around the protein bodies and only to some extent along the plasmalemma. Amyloplasts (am) are readily found in both tissues, although the amyloplasts of the epithelium are smaller and less frequent. Mitochondria (mi), endoplasmic reticulum (er) and Golgi apparatuses (go) are present in both cell types. nu, nucleus. (Bar $=2 \mu \mathrm{m}$ ).

2 B. Higher magnification of the upper framed area in Figure 2 A. Rough endoplasmic reticulum and Golgi apparatuses are present, and one amyloplast is located to the left in the micrograph. Mitochondria are also seen. ol, olesome. (Bar $=0.5 \mu \mathrm{m})$.

$2 \mathrm{C}$. Higher magnification of the lower framed area in Figure $2 \mathrm{~A}$. The amyloplast shown in the micrograph contains granular ground substance, a starch granule and internal membranes. Rough endoplasmic reticulum is located close to the amyloplast. (Bar $=0.5 \mu \mathrm{m}$ ).

$2 \mathrm{D}$. Longitudinal section of the seed used for the ultrathin sectioning, stained with calcofluor and photographed in UV-light. Cell walls in the region near the scutellum are degraded. The arrow denotes the position, at which the section in Figure $2 \mathrm{~A}$ has been cut. em, embryo; en, endosperm. (Bar $=1 \mathrm{~mm}$ ).

Figure 3. Cross section through the scutellum in a barley seed 162 hours after the start of malting.

$3 \mathrm{~A}$. Survey micrograph showing parenchyma (upper part) and epithelium (lower part). In the parenchyma cells, vacuoles (va) and protein bodies are not as dominant as in Figure $2 \mathrm{~A}$. In the epithelium vacuoles are now seen together with electron transparent protein bodies. In both cell types the oleosomes (ol) are apparently distributed at random. Large amyloplasts (am) are frequent in the parenchyma, while in the epithelium the amyloplasts are smaller and less frequent. Golgi apparatuses (go) and endoplasmic reticulum (er) are readily found in the epithelium. mi, mitochondrion; nu, nucleus; pl, plasmodesma. (Bar $=2 \mu \mathrm{m}$ ).

3 B. Higher magnification of the upper framed area in Figure $3 \mathrm{~A}$, showing mitochondria and one Golgi apparatus. Note the plasmodesmata $(\mathrm{pl})$ connecting the two cells. $(\mathrm{Bar}=2 \mu \mathrm{m})$.

$3 \mathrm{C}$. Higher magnification of the lower framed area in Figure $3 \mathrm{~A}$. One Golgi apparatus is located near the cell wall, and free ribosomes are present in the cytoplasm. Rough endoplasmic reticulum is observed close to the amyloplast. The amyloplast is probably dividing. as indicated by the constriction of the outer membrane. (Bar = $0.5 \mu \mathrm{m})$.

$3 \mathrm{D}$. Longitudinal section of the seed used for the ultrathin sectioning, stained with calcofluor and photographed in UV-light. Degraded endosperm now covers a large area in the embryo end of the seed. The arrow denotes the position, at which the section in Figure $3 \mathrm{~A}$ has been cut. co, coleoptile; em, embryo; en, endosperm. $($ Bar $=1 \mathrm{~mm})$. 

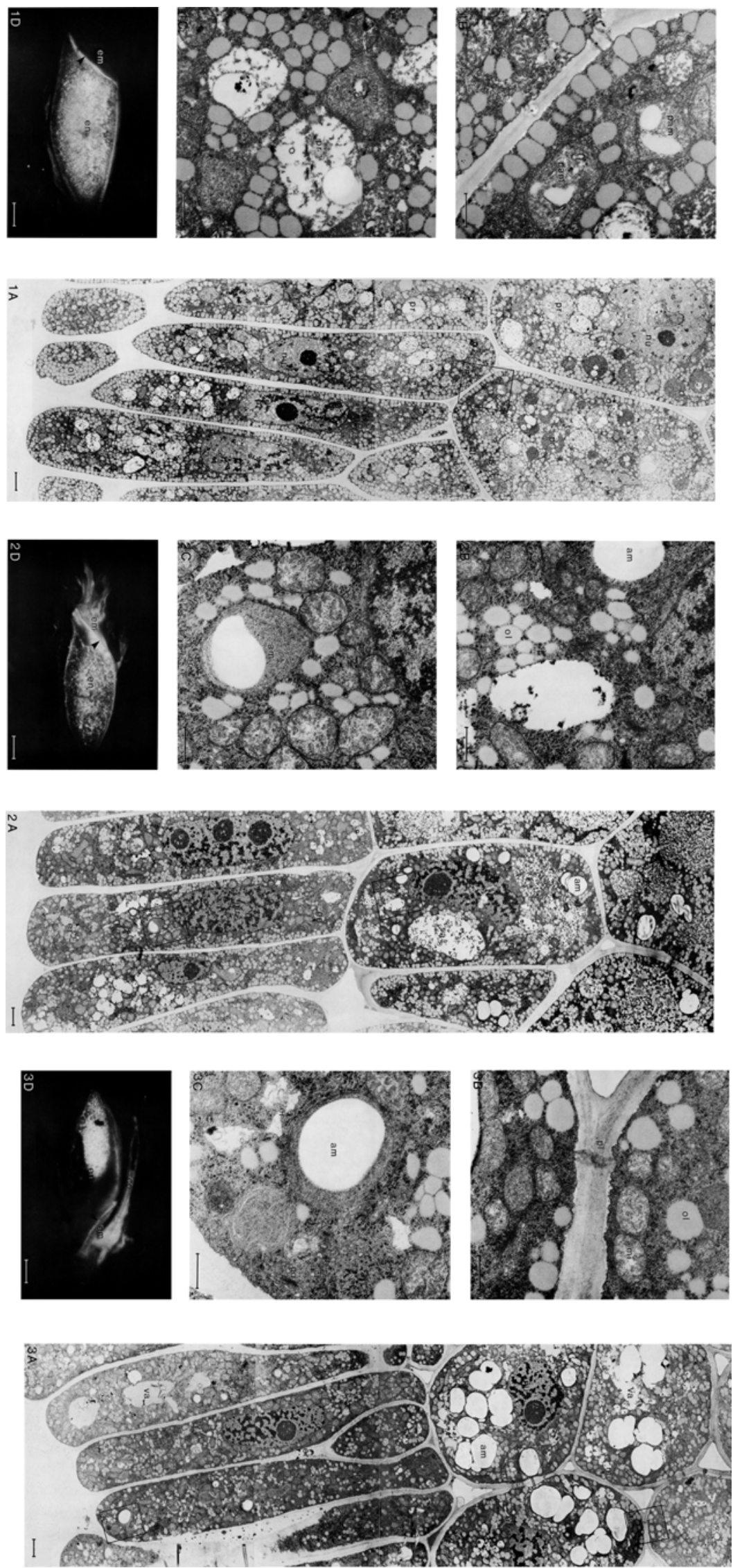